\title{
Botanical Diversity at Savura, a Lowland Rain Forest Site along the PABITRA Gateway Transect, Viti Levu, Fiji ${ }^{1}$
}

\author{
Gunnar Keppel, ${ }^{2}$ Fone Cawani Navuso, ${ }^{2}$ A. Naikatini,${ }^{4}$ Nunia T. Thomas, ${ }^{4}$ Isaac A. Rounds, ${ }^{2,4}$ \\ Tamara A. Osborne, ${ }^{5}$ Nemani Batinamu, ${ }^{3}$ and Eliki Senivasa ${ }^{3}$
}

\begin{abstract}
Savura is one of the seven focal sites of the Pacific-Asia Biodiversity Transect (PABITRA) Gateway Transect in Fiji. The site is composed of tropical lowland rain forest located in southeastern Viti Levu and consists of two adjacent watershed reserves, the Savura Forest Reserve and the Vago Forest Reserve. A total of 560 indigenous species (52\% endemic) of vascular plants is recorded for this focal site. Savura has been chosen for the establishment of a large permanent plot of 12 ha following the methods proposed by the Centre of Tropical Forest Science (CTFS). This involves the recording of name, diameter at breast height $(\mathrm{DBH})$, and precise location of every tree with $1 \mathrm{~cm}$ or more DBH. A total of 5,494 individuals with a total basal area of $2,752 \mathrm{~m}^{2}$ was recorded in the first $6,000 \mathrm{~m}^{2}$ of this CTFS/PABITRA permanent plot. The Myristicaceae (species of the genus Myristica) was the dominant family in numbers of individuals (14.4\%) and basal area (35.6\%). Tree ferns (Cyatheaceae [ $8.2 \%$ of individuals, $14.6 \%$ basal area]) and the Clusiaceae ( $8.6 \%$ of individuals, $12.8 \%$ basal area) are other major components. After this initial census, subsequent censuses will be carried out every $5 \mathrm{yr}$ and should give insights on spatial dynamics, recruitment and mortality, and long-term changes in populations of tree species.
\end{abstract}

Savura, one of the seven focal sites of the Fiji Pacific-Asia Biodiversity Transect (PABITRA) wet-zone transect (Keppel 2005, this issue), is located in the province of Naitasiri and includes two adjacent forest reserves, Vago and Savura, that are catchment areas for Savura Creek, which provides much of Suva's water supply (Figure 1). The Vago Forest Reserve was established in 1959 and

${ }^{1}$ The Savura 12-ha Permanent Plot is funded by the University Research Committee (URC) of the University of the South Pacific, Suva, Fiji. Manuscript accepted 23 April 2004.

${ }^{2}$ Biology Department, School of Pure and Applied Sciences, University of the South Pacific, Suva, Fiji.

${ }^{3}$ Forestry Department, Ministry of Fisheries and Forests, Suva, Fiji.

${ }^{4}$ South Pacific Regional Herbarium, Institute of Applied Sciences, University of the South Pacific, Suva, Fiji.

${ }^{5}$ Geography Department, University of the South Pacific, Suva, Fiji.

Pacific Science (2005), vol. 59, no. 2:175-191

(C) 2005 by University of Hawai'i Press

All rights reserved comprises 24.7 ha of lowland rain forest; the Savura Forest Reserve was established in 1963 and comprises 396.5 ha. No trees have been removed from either reserve since their establishment, but before that, traditional logging, the occasional removal of large trees for house construction, is likely to have occurred at least in parts of the reserves.

Because of its comparative accessibility and its protected status, Savura and the surrounding areas have been subject to previous botanical collections and ecological studies investigating the demography of Balaka microcarpa Burret (Ash 1988) and Cyathea hornei Baker (Copel.) (Ash 1987). Despite this, no species list for the area exists. In this paper we provide a preliminary list of species by incorporating data from collections at the South Pacific Regional Herbarium and from specimens listed in Smith (1979, 1981, 1985, 1988, 1991, 1996) and in Brownlie (1977). Also included are species recorded from an altitudinal transect on adjacent Mt. Korobaba (Hassal and Kirkpatrick 1985, Kirkpatrick and Hassal 1985), which is similar in altitude 


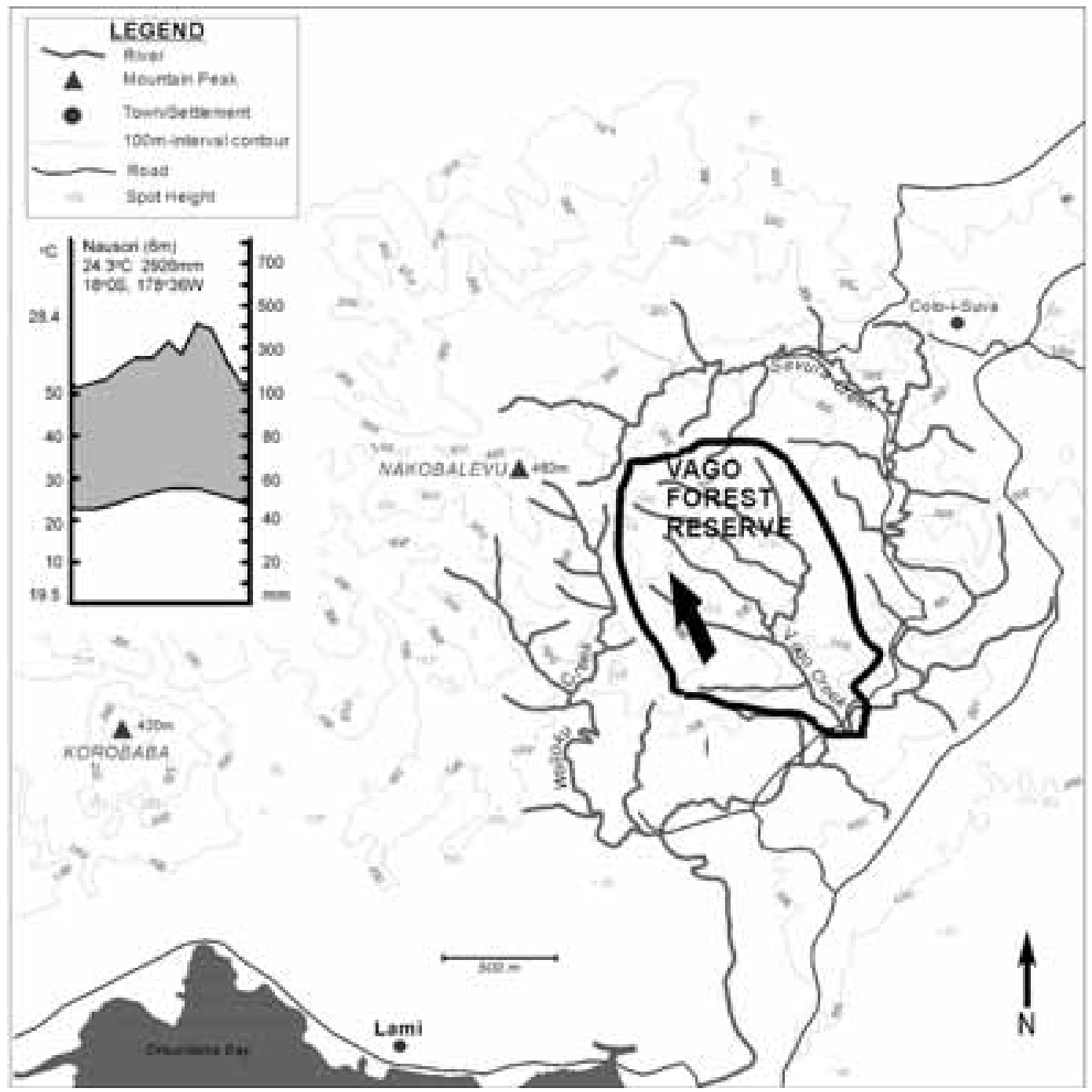

FIGURE 1. Map showing the boundary of the Vago Forest Reserve and location of the study site for the 12-ha permanent plot (indicated by arrow). The map also shows Savura Creek and Wailoku Creek, which are part of the Savura Forest Reserve and the Wailoku Forest Reserve, respectively. Inset is the climate diagram for Nausori Airport, located $14 \mathrm{~km}$ east of Savura.

to Mt. Nakobalevu in the Savura focal site (see Figure 1).

Currently, a 12-ha permanent plot is being created in the Vago Forest Reserve following Centre for Tropical Forest Science (CTFS) protocol (Condit 1998), which involves mapping, measuring, and identification of every tree that is $1 \mathrm{~cm}$ or more in diameter. The project is a joint effort between the University of the South Pacific and the Fiji Forestry Department. After completion of the initial census, which is anticipated by early 2005 , the plot will be revisited every $5 \mathrm{yr}$. In this paper we present a preliminary species list, profile 
diagrams, and initial preliminary results of the first $6,000 \mathrm{~m}^{2}$ of this CTFS/PABITRA permanent plot.

\section{MATERIALS AND METHODS}

\section{Study Area}

The Savura focal site is located in southeastern Viti Levu, about $8 \mathrm{~km}$ north of Suva. It is mostly covered by lowland rain forest. The climate diagram of Nausori (Suva) Airport (Figure 1 inset), located $14 \mathrm{~km}$ east of the focal site, shows a mean annual rainfall of 2,926 $\mathrm{mm}$ and a perhumidity index (Walsh 1992) of 20. Nausori Airport is located on the floodplain of Fiji's largest river, the Rewa, therefore the focal site is likely to receive more rainfall due to additional orographic rainfall. The climate may be best described as tropical wet to superwet (Richards 1996). Topography is very uneven with steep slopes and ridges. Landslides are common.

To begin the study and to provide some species identification the first hectare of the permanent plot (which is intended to be 12 ha in size) has been set up in the Vago Reserve (see Figure 1). Data collection for this study was restricted to the first $6,000 \mathrm{~m}^{2}$ of the initial 1-ha plot. Because of the dense canopy, global positioning system (GPS) readings are difficult to obtain in the forest. However, GPS coordinates obtained near the bottom of the nearby Vago Waterfall in the same reserve were $18^{\prime} 04.833^{\prime \prime} \mathrm{S}$ and $178^{\prime} 26.505^{\prime \prime}$ E (D. Boseto, pers. comm.).

\section{Preliminary Species List}

A species list of plants likely to be encountered was constructed by listing all species reported from Savura, Vago, Wailoku, Coloi-Suva, Mt. Nakobalevu, and Mt. Korobaba (see Figure 1 for locations). These records were obtained from Flora Vitiensis Nova (Smith 1979, 1981, 1985, 1988, 1991, 1996), the database of the South Pacific Regional Herbarium, and a previous study on Mt. Korobaba (Kirkpatrick and Hassal 1985). Planted ornamentals were ignored. Smith's volumes $(1979,1981,1985,1988,1991,1996)$ were used to assess whether a species is endemic, indigenous, or introduced.

\section{Profile Diagrams}

Profile diagrams were constructed by placing two 60 by $6 \mathrm{~m}$ transects into homogeneous vegetation types. One was placed on a slope and the other on a plain. Within each of these transects every tree of $10 \mathrm{~cm}$ or more in diameter at breast height (DBH) was identified and approximately mapped. For each such tree $\mathrm{DBH}$ was measured and the bole height, crown height, and crown width estimated. These data were then used to draw a profile diagram.

\section{Tree Census}

Within the $6,000 \mathrm{~m}^{2}$ every tree with a $\mathrm{DBH}$ of $1 \mathrm{~cm}$ or more was measured, tagged, identified, and mapped following Condit (1998). However, instead of aluminum tags, nylon ribbons (with numbers written using white correction fluid) were used for this initial census. Tree identifications were made by J.C.N. and G.K. using parataxonomy (vernacular names). This involves identification of trees based on characteristics of the bark and other vegetative features and allows identification of plants to the family, genus, or species level, depending on the plant. Scientific identification of the various species is currently under way. In addition, Neil White (Biology Department, University of the South Pacific) has created an MS Access database following the format suggested by Condit (1998) and data entry will commence once identifications to the species level are completed.

\section{RESULTS}

\section{Species}

A total of 560 indigenous species $(52 \%$ endemic) was recorded (see Appendix 1). Of these, 345 ( $71 \%$ endemic) were dicotyledons, 117 (28\% endemic) were ferns, 93 (14\% endemic) were monocotyledons, and 5 (none endemic) were gymnosperms; 55 of the 93 monocotyledonous species were orchids. In addition 27 introduced species were recorded. 


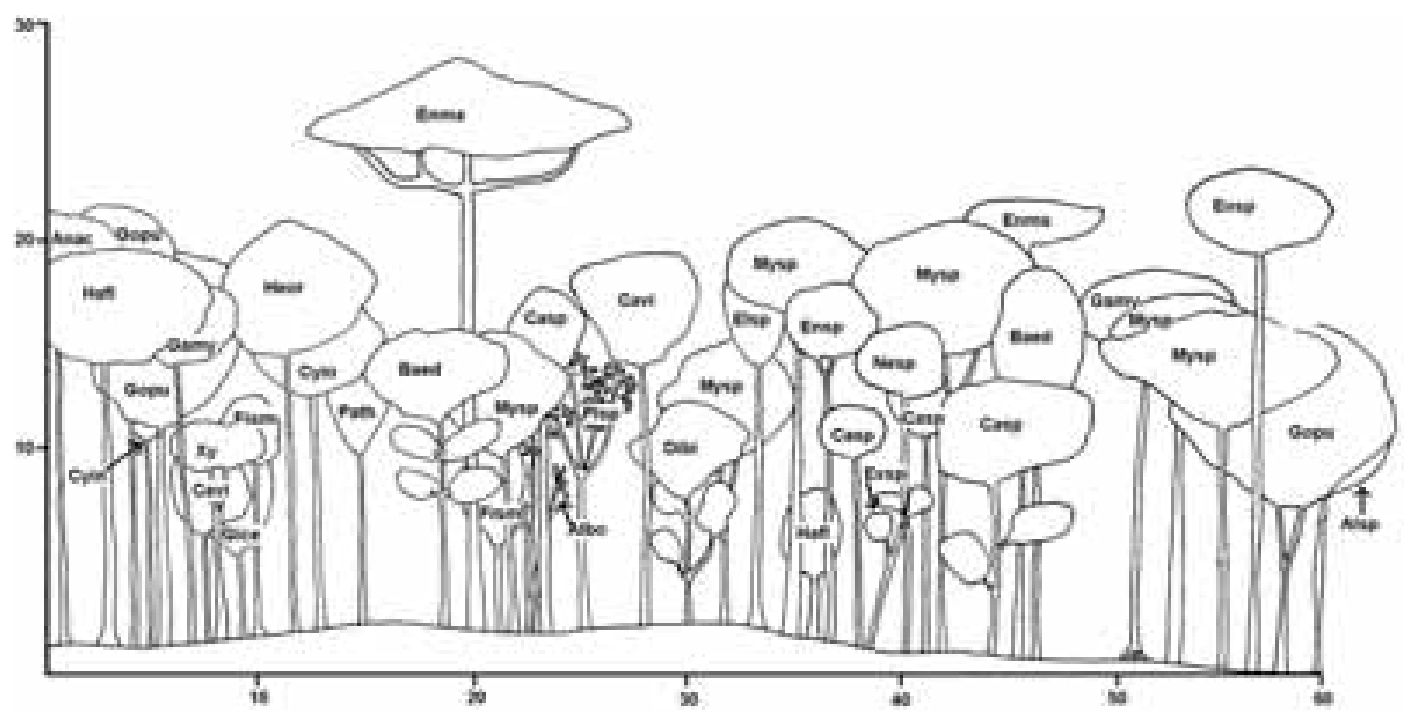

Figure 2. Forest profile diagram of lowland rain forest on a plain in Savura, Naitasiri Province, Fiji. Symbols of trees over 10 cm DBH: Albo, Alpinia boia; Alsp, Alstonis sp.; Anac, Buchanania sp.; Baed, Barringtonia edulis; Casp, Canarium sp.; Cavi, Calophyllum vitiense; Cyin, Cyathocalyx insularis; Dibi, Dillenia biflora; Elsp, Elaeocarpus sp.; Enma, Endospermum macrophyllum; Ensp, Endiandra sp.; Exsp, Excoecaria sp.?; Fism, Ficus smithii; Gamy, Garcinia myrtiflora; Gice, Gironniera celtidifolia; Gopu, Gonystylus punctatus; Hafl, Haplolobus floribundus; Heor, Heritiera ornithocephala; Mysp, Myristica sp.; Nesp, Neuburgia sp.; Path, Pagiantha thurstonii; Plsp, Plerandra sp.; Xy, Xylopia sp.

\section{Profile Diagrams}

The profile diagrams (Figures 2 and 3) show that species of Myristica dominate the canopy and subcanopy with emergents of Endospermum macrophyllum on plains, and Calophyllum vitiense, Gonystylus punctatus, and species of Syzygium dominate the canopy and subcanopy on slopes.

\section{Permanent Plot}

In the first $6,000 \mathrm{~m}^{2}, 5,494$ individuals in 47 families with diameter of $1 \mathrm{~cm}$ or more were recorded. Of these, 5,474 individuals were identified at least to family level, and 20 remained unidentified (Appendix 2). The total basal area of these trees amounted to 2,752 $\mathrm{m}^{2}$. Admittedly, there is potential for some erronous identifications, but these are likely to be minimal at the family level. We estimate erroneous identifications to amount to less than 50 individuals, but it may be as high as 100 individuals. Only after herbarium identification of the species can the exact size of error using the parataxonomic method be known.

Species of Myristica (Myristicaceae) are dominant in the area surveyed. They account for $14.4 \%$ of individuals (Table 1) and for $35.6 \%$ of the basal area (Table 2). The Clusiaceae (species of Calophyllum and Garcinia) and tree ferns (species of Cyathea [Cyatheaceae]) were other very common families, composing more than $8 \%$ of individuals and more than $14 \%$ of basal area. Other common families that composed more than $1 \%$ of basal area are the Lauraceae, Myrtaceae, Gonystylus punctatus (Thymeliaceae), Sapotaceae, Euphorbiaceae, Meliaceae, Burseraceae, species of Barringtonia (Lecythidaceae), Chrysobalanaceae, Araliaceae, and the Moraceae.

\section{DISCUSSION}

A large number of indigenous species (560) was recorded. This was more than the 426 species recorded at Waisoi, another lowland rain forest site on Viti Levu (Tuiwawa 1999). This is likely due to the proximity of 


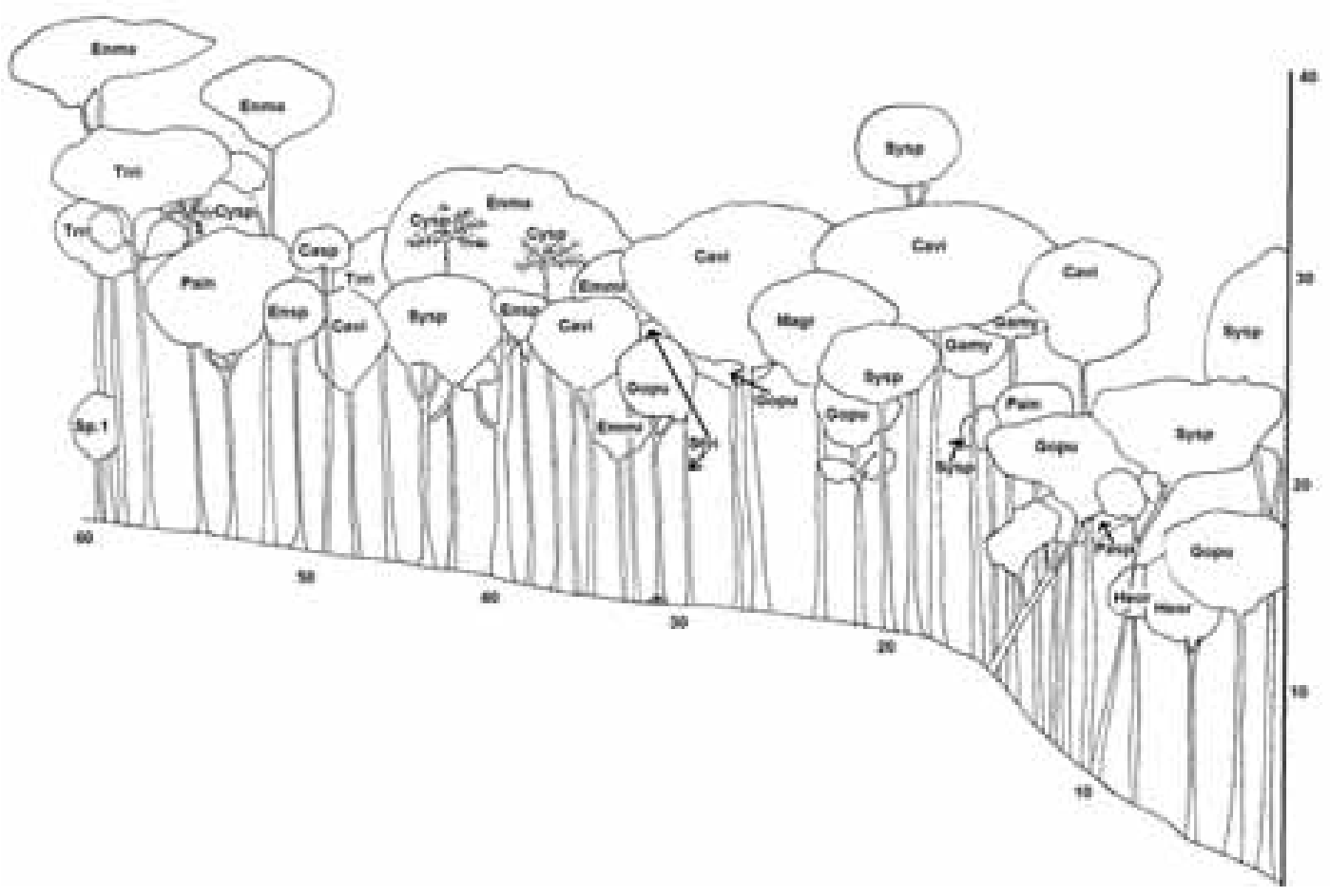

Figure 3. Forest profile diagram of a mixed-species lowland rain forest on a slope in the Vago Reserve, Savura. Symbols of trees over $10 \mathrm{~cm}$ DBH: Sp. 1, unknown; Casp, Canarium sp.; Cavi, Calophyllum vitiense; Cysp, Cyathea sp.; Emmi, Emmenosperma micropetalum; Enma, Endospermum macrophyllum; Ensp, Endiandra sp.; Gamy, Garcinia myrtiflora; Gopu, Gonystylus punctatus; Heor, Heritiera ornithocephala; Magr, Maniltoa grandiflora; Pain, Parinari insularum; Pasp, Palaquium sp.; Stvi, Storckiella vitiensis; Sysp, Syzygium sp.; Trri, Trichospermum richii.

Savura to Suva and the University of the South Pacific, the base for many local and visiting botanists, whereas the results in Waisoi are based on a single, but extensive, study.

Several species of special scientific interest were recorded: three members of the ancient and eusporangiate fern family Marattiaceae, the conifers Agathis macrophylla and Podocarpus neriifolius, the giant ginger Alpinia boia, and Degeneria vitiensis, one of the two remaining species in the "Gondwanan relic" family Degeneriaceae (endemic to Fiji). All these are found within a subsample of the planned 12-ha permanent plot.

In terms of number of individuals (14.4\%) and basal area (35.6\%), Myristicaceae was the dominant family. There are four species of Myristica that contribute to this: $M$. castaneifolia, M. chartacea, M. gillespieana, and M. ma- crantha. If basal area is considered, there are two other principal families (having a relative abundance of $10 \%$ or more [after Tanner 1977]), the Cyatheaceae (14.6\%) and the Clusiaceae $(12.8 \%)$. The great abundance of the Myristicaceae is obvious on the profile diagram of the flat (Figure 2). However, the abundance of tree ferns (indicated by only three individuals) on the profile diagram of the slope community (Figure 3) questions the representativeness of such profile diagrams or any studies using a $10-\mathrm{cm}$ DBH cutoff.

The great abundance of tree ferns (Cyatheaceae) in relatively undisturbed lowland rain forest is a previously unreported phenomenon. We suggest that two major factors contribute to this. First, tree ferns and Alpinia boia appear to be the first colonizers of tree 
TABLE 1

The 20 Most Abundant Plant Families Arranged in Decreasing Abundance in Number of Individuals in the $6,000-\mathrm{m}^{2}$ Plot in Vago Forest Reserve

\begin{tabular}{lcr}
\hline \hline & $\begin{array}{c}\text { No. of Individuals } \\
(n)\end{array}$ & $\%$ \\
\hline Family & 745 & 14.4 \\
Myristicaceae & 446 & 8.6 \\
Clusiaceae & 424 & 8.2 \\
Cyatheaceae & 299 & 5.8 \\
Meliaceae & 297 & 5.7 \\
Lauraceae & 277 & 5.3 \\
Sapotaceae & 275 & 5.3 \\
Myrtaceae & 203 & 3.9 \\
Lecythidaceae & 194 & 3.7 \\
Thymeleaceae & 158 & 3.1 \\
Euphorbiaceae & 148 & 2.9 \\
Moraceae & 137 & 2.6 \\
Gnetaceae & 133 & 2.6 \\
Chrysobalanaceae & 119 & 2.3 \\
Burseraceae & 118 & 2.3 \\
Araliaceae & 110 & 2.1 \\
Rubiaceae & 106 & 2.0 \\
Loganiaceae & 95 & 1.8 \\
Ulmaceae & 81 & 1.6 \\
Dilleniaceae & & \\
\hline
\end{tabular}

fall and landslide gaps at the study site. Second, tree ferns appear to be more common on the slopes in Fiji's lowland rain forest (Tuiwawa 1999). Because the study site has many unstable slopes prone to seemingly frequent landslides, tree ferns are extremely abundant. Upon completion of the first census of the 12-ha plot, it will be possible to test whether tree ferns are more abundant in gaps and on slopes than on plains in the study site. The profile diagrams (Figures 2 and 3) suggest that the slopes and flats are dominated by different plant assemblages; therefore, there is a high likelihood to discover distinct slope, flat, and ridge communities as in Waisoi (Tuiwawa 1999).

The initial census should also produce similar spatial information about many other species, some of which are commercial timber species. It should also provide insights into the structure and composition of Fiji's lowland rain forests. Subsequent censuses, which are to be carried out every $5 \mathrm{yr}$, will help to provide more detailed long-term ecological

TABLE 2

The 20 Most Abundant Plant Families Arranged in Decreasing Basal Area as Determined by Diameter at Breast Height (DBH) in the $6,000-\mathrm{m}^{2}$ Plot in Vago Forest Reserve

\begin{tabular}{lcccc}
\hline \hline Family & $\begin{array}{c}\text { Maximum DBH } \\
(\mathrm{cm})\end{array}$ & $\begin{array}{c}\text { Mean DBH } \\
(\mathrm{cm})\end{array}$ & $\begin{array}{c}\text { Total Basal Area } \\
\left(\mathrm{m}^{2}\right)\end{array}$ & $\begin{array}{c}\text { Basal Area } \\
(\%)\end{array}$ \\
\hline Myristicaceae & 467 & 47.4 & 978.96 & 35.6 \\
Cyatheaceae & 234 & 25.5 & 401.08 & 14.6 \\
Clusiaceae & 485 & 47.3 & 351.15 & 12.8 \\
Lauraceae & 434 & 48.1 & 161.40 & 5.4 \\
Myrtaceae & 565 & 49.6 & 149.43 & 4.0 \\
Thymeleaceae & 647 & 60.8 & 109.25 & 3.8 \\
Sapotaceae & 332 & 44.5 & 103.60 & 2.9 \\
Euphorbiaceae & 657 & 64.1 & 80.70 & 2.6 \\
Meliaceae & 284 & 37.2 & 71.47 & 1.7 \\
Burseraceae & 409 & 70.2 & 53.91 & 1.4 \\
Lecythidaceae & 222 & 37.8 & 46.30 & 1.2 \\
Chrysobalanaceae & 297 & 53.3 & 39.38 & 1.1 \\
Araliaceae & 373 & 55.1 & 33.17 & 0.6 \\
Moraceae & 155 & 42.4 & 30.93 & 0.6 \\
Hernandiaceae & 350 & 82.1 & 17.70 & 0.6 \\
Dilleniaceae & 448 & 17.48 & 0.4 \\
Apocynaceae & 343 & 70.8 & 17.15 & 0.4 \\
Caesalpinaceae & 367 & 44.3 & 10.21 & 0.3 \\
Gnetaceae & 70 & 26.3 & 10.20 & 9.59 \\
Loganiaceae & 124 & 33.1 & & \\
\hline
\end{tabular}


information about the different species in terms of spatial dynamics, recruitment and mortality, and intra- and interspecific interactions.

Repeated monitoring will also allow documentation of the behavior of invasive species. The African tulip tree (Spathodea campanulata) is currently the most widespread invasive tree species on Viti Levu and may be one of the biggest threats to Fiji's biodiversity. At the study site, however, it is currently restricted to the banks of streams and forest edges. Another major concern is the commercially planted mahogany (Swietenia macrophylla), which appears to be escaping cultivation. Three saplings were recorded (Appendix 2) in the first $6,000 \mathrm{~m}^{2}$, with the seeds likely to have originated from the Colo-i-Suva mahogany plantation located about $1 \mathrm{~km}$ to the east of the study plot. Other invasives that could possibly alter the forest composition and structure and were seen in close proximity to the study site are the red bead tree (Adenanthera pavonia) and the Australian umbrella tree (Schefflera actinophylla).

Although the data are to be collected following CTFS guidelines, databasing will allow easy extraction of the information required for PABITRA. There is a need to collect data on species composition and vegetation structure in other areas, because the permanent plot will only cover 12 ha of the 421 ha of the two reserves (Vago and Savura) that constitute this PABITRA focal site. We believe that this should ideally include additional plots in an altitudinal transect on Mt. Nakobalevu. This would allow a comparison with the vegetation surveys from Mt. Korobaba (Kirkpatrick and Hassal 1985).

\section{ACKNOWLEDGMENTS}

We thank the South Pacific Regional Herbarium for granting us access to their still expanding database. We are also grateful to the following individuals, who were involved in and have contributed to the project: Margaret Fox, Lynette Petueli, Joape Kuruyawa, Simone Narube, and Inoke Wainiqolo. A big vinaka vaka levu also to Prof. Dieter MuellerDombois, who kindly reviewed this paper.

\section{Literature Cited}

Ash, J. 1987. Demography of Cyathea hornei (Cyatheaceae), a tropical tree fern from Fiji. Aust. J. Bot. 35:331-342.

. 1988. Demography and production of Balaka microcarpa (Arecaceae), a tropical understorey palm from Fiji. Aust. J. Bot. 36:67-80.

Brownlie, G. 1977. The pteridophyte flora of Fiji. (Beihefte zur Nova Hedwigia, Heft 55). A. R. Ganther Verlag KG., Vaduz, Liechtenstein.

Condit, R. 1998. Tropical forest census plots: Methods and results from Barro Colorado Island, Panama and a comparison with other plots. Springer Verlag, Berlin, Germany.

Doyle, M. F. 1998. Gymnosperms of the SW Pacific-I. Fiji. Endemic, indigenous, and naturalized species: Changes in nomenclature, key, annotated checklist, and discussion. Harv. Pap. Bot. 3:101-106.

Hassal, D. C., and J. B. Kirkpatrick. 1985. The diagnostic value and host relationships of the dependent synusia in the forests of Mount Korobaba, Fiji. N. Z. J. Bot. 23:33-46.

Keppel, G. 2005. Botanical studies within the PABITRA wet-zone transect, Viti Levu, Fiji. Pac. Sci. 59:165-174 (this issue).

Kirkpatrick, J. B., and D. C. Hassal. 1985. The vegetation and flora along an altitudinal transect through a tropical forest at Mount Korobaba, Fiji. N. Z. J. Bot. 23:33-46.

Richards, P. W. 1996. The tropical rain forest. Cambridge University Press, Cambridge, U.K.

Smith, A. C. 1979. Flora Vitiensis nova: A new flora of Fiji (spermatophytes only). Vol. 1. Pacific Tropical Botanical Garden, Lāwa'i, Kaua'i, Hawai'i.

-1981. Flora Vitiensis nova: A new flora of Fiji (spermatophytes only). Vol. 2. Pacific Tropical Botanical Garden, Lāwa'i, Kaua'i, Hawai'i.

-1985. Flora Vitiensis nova: A new flora of Fiji (spermatophytes only). Vol. 3. Pacific Tropical Botanical Garden, Lāwa'i, Kaua'i, Hawai'i. 
1988. Flora Vitiensis nova: A new

flora of Fiji (spermatophytes only). Vol. 4. Pacific Tropical Botanical Garden, Lāwa'i, Kaua'i, Hawai'i.

1991. Flora Vitiensis nova: A new

flora of Fiji (spermatophytes only). Vol. 5. Pacific Tropical Botanical Garden, Lāwa'i, Kaua'i, Hawai'i.

1996. Flora Vitiensis nova: A new

flora of Fiji (spermatophytes only): Comprehensive indices. Pacific Tropical Botanical Garden, Lāwa'i, Kaua'i, Hawai'i.

Tanner, E. V. J. 1977. Four montane rainforests of Jamaica: A quantitative characterisa- tion of the floristics, the soils and the foliar mineral levels, and a discussion of the interrelations. J. Ecol. 65:883-918.

Tuiwawa, M. 1999. The flora, ecology and conservation of the botanical biodiversity of Waisoi and the southeasterm slopes of the Korobasaga Range in Namosi Province, Fiji. M.S. thesis, University of the South Pacific, Suva, Fiji.

Walsh, R. P. D. 1992. Representation and classification of tropical climates for ecological purposes using the perhumidity index. Swansea Geogr. 24:109-129.

Appendix 1

Preliminary Species Checklist for the Savura Focal Site

\begin{tabular}{|c|c|}
\hline Ferns and Fern Allies & $\begin{array}{l}\text { Tectaria hookerii Brownlie } \\
\text { Tectaria vitiensis Brownlie }\end{array}$ \\
\hline $\begin{array}{l}\text { PSILOTACEAE } \\
\text { Psilotum complanatum Sw. }{ }^{\mathrm{I}} \\
\text { Psilotum nudum } \text { (L.) P. B. }{ }^{\mathrm{I}}\end{array}$ & $\begin{array}{l}\text { ASPLENIACEAE } \\
\text { Asplenium amboinense Willd. }{ }^{\mathrm{I}} \\
\text { Asplenium austalasicum } \mathrm{Hk}^{\mathrm{I}} \\
\text { Asplenium bipinnatifidum } \text { Baker }^{\mathrm{I}}\end{array}$ \\
\hline Lycopsida & Asplenium cuneatum Lam. ${ }^{\mathrm{I}}$ \\
\hline $\begin{array}{l}\text { LYCOPSIDACEAE } \\
\text { Lycopodium carinatum } \text { Desv. }^{\mathrm{I}}\end{array}$ & $\begin{array}{l}\text { Asplenium unilaterale Lam. }{ }^{\mathrm{I}} \\
\text { Loxoscaphe gibberosum (Forst.) Moore }\end{array}$ \\
\hline Lycopodium cernuum L.I & ATHYRIACEAE \\
\hline Lycopodium floliosum Copel. ${ }^{\mathrm{E}}$ & Diplazium bulbiferum Brack. ${ }^{\mathrm{I}}$ \\
\hline Lycopodium phlegmaria L.I & Diplazium harpeodes Moore ${ }^{\mathrm{I}}$ \\
\hline $\begin{array}{l}\text { Lycopodium squarrosum } \text { Forst. }^{\mathrm{I}} \\
\text { Lycopodium subtrifoliatum } \text { Brownlie }^{\mathrm{E}}\end{array}$ & Diplazium melanocaulon Brack. ${ }^{\mathrm{I}}$ \\
\hline Lycopodium trifoliatum Copel. ${ }^{\mathrm{E}}$ & $\begin{array}{l}\text { BLECHNACEAE } \\
\text { Blechnum coriaceum (Brack.) Brownlie }{ }^{\mathrm{E}}\end{array}$ \\
\hline $\begin{array}{l}\text { SELAGINELLACEAE } \\
\text { Selaginella brynioides } \text { Baker }{ }^{\mathrm{E}} \\
\text { Selaginella distans Warburg }{ }^{\mathrm{E}} \\
\text { Selaginella firmula A. Br. ex Kuhn }{ }^{\mathrm{I}} \\
\text { Selaginella rechingeri Hieronymus ex Rech. }{ }^{\mathrm{I}}\end{array}$ & $\begin{array}{l}\text { Blechnum milnei (Carr.) C. Christensen }{ }^{\mathrm{E}} \\
\text { Blechnum orientale L.I } \\
\text { Blechnum pilosum (Brack.) Brownlie }{ }^{\mathrm{E}} \\
\text { Blechnum vittatum Brack. } \\
\text { Doodia brackenridgei Carr. ex Seem. }\end{array}$ \\
\hline Filicopsida & $\begin{array}{l}\text { CYATHEACEAE } \\
\text { Culcita straminea (Labill.) Maxon }{ }^{\mathrm{I}}\end{array}$ \\
\hline $\begin{array}{l}\text { ADIANTACEAE } \\
\text { Adiantun bornei } \text { Baker }^{\mathrm{E}} \\
\text { Pteris litoralis } \text { Rech. }{ }^{\mathrm{I}} \\
\text { Pteris parbamii } \text { Brownlie }^{\mathrm{E}} \\
\text { Pteris vitiensis } \text { Baker }{ }^{\mathrm{E}} \\
\text { Pteris vittata } \text { L. }{ }^{\mathrm{I}} \\
\text { Stenochalena palustris (Burm.) Bedd. }{ }^{\mathrm{I}}\end{array}$ & $\begin{array}{l}\text { Cyathea affinis (Forst.) Sw. } \\
\text { Cyathea alta } \text { Copel. } \\
\text { Cyathea decurrens } \text { (Hk.) Copel. }{ }^{\mathrm{I}} \\
\text { Cyathea bornei (Baker) Copel. }{ }^{\mathrm{I}} \\
\text { Cyathea lunulata (Forst.) Copel. } \\
\text { Cyathea propinqua Mett. } \\
\text { Dicksonia brackenridgei Mett. }{ }^{\mathrm{E}}\end{array}$ \\
\hline $\begin{array}{l}\text { Syngramma borneensis (Hk.) J. Sm. }{ }^{\mathrm{I}} \\
\text { Syngramma spatbulata (C. Christ.) Holtt. } \\
\text { Taenitis pinnata var. polypodioides (Baker) Holtt. }{ }^{\mathrm{I}} \text { (var. E) }\end{array}$ & $\begin{array}{l}\text { DAVALLIACEAE } \\
\text { Arthopteris articulata (Brack.) C. Chr. }{ }^{\mathrm{I}} \\
\text { Arthopteris repens (Brack.) C. Chr. }\end{array}$ \\
\hline $\begin{array}{l}\text { ASPIDIACEAE } \\
\text { Ctenitis fijiensis } \text { (Hk.) Copel. }{ }^{\mathrm{E}} \\
\text { Tectaria crenata Cav. }{ }^{\mathrm{I}}\end{array}$ & $\begin{array}{l}\text { Davallia fejeensis } \mathrm{Hk}^{\mathrm{E}} \\
\text { Davallia solida (Forst.) Sw. } \\
\text { Humata botrychioides } \text { Brack }^{\mathrm{E}}\end{array}$ \\
\hline
\end{tabular}


Appendix 1 (continued)

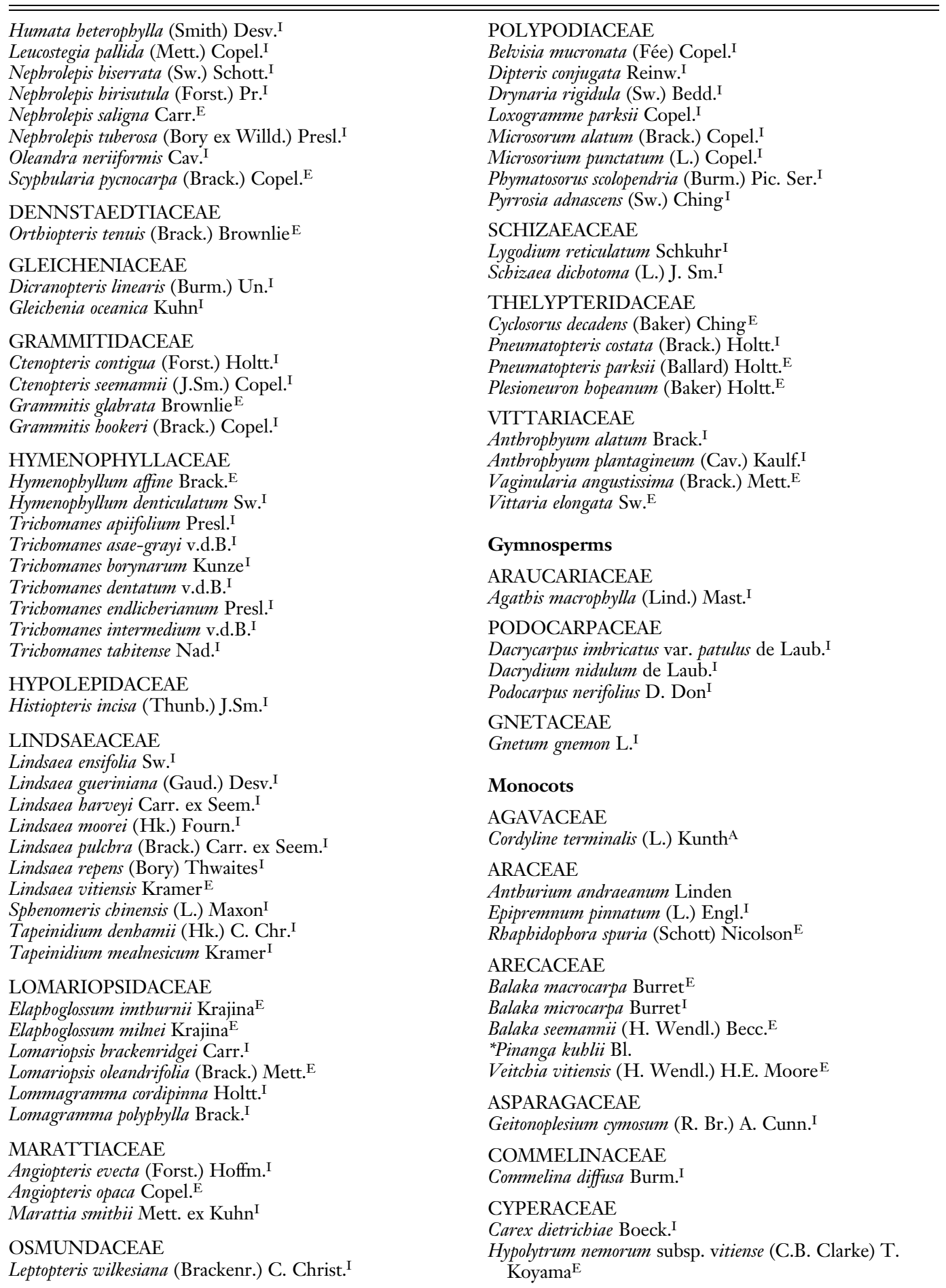


Appendix 1 (continued)

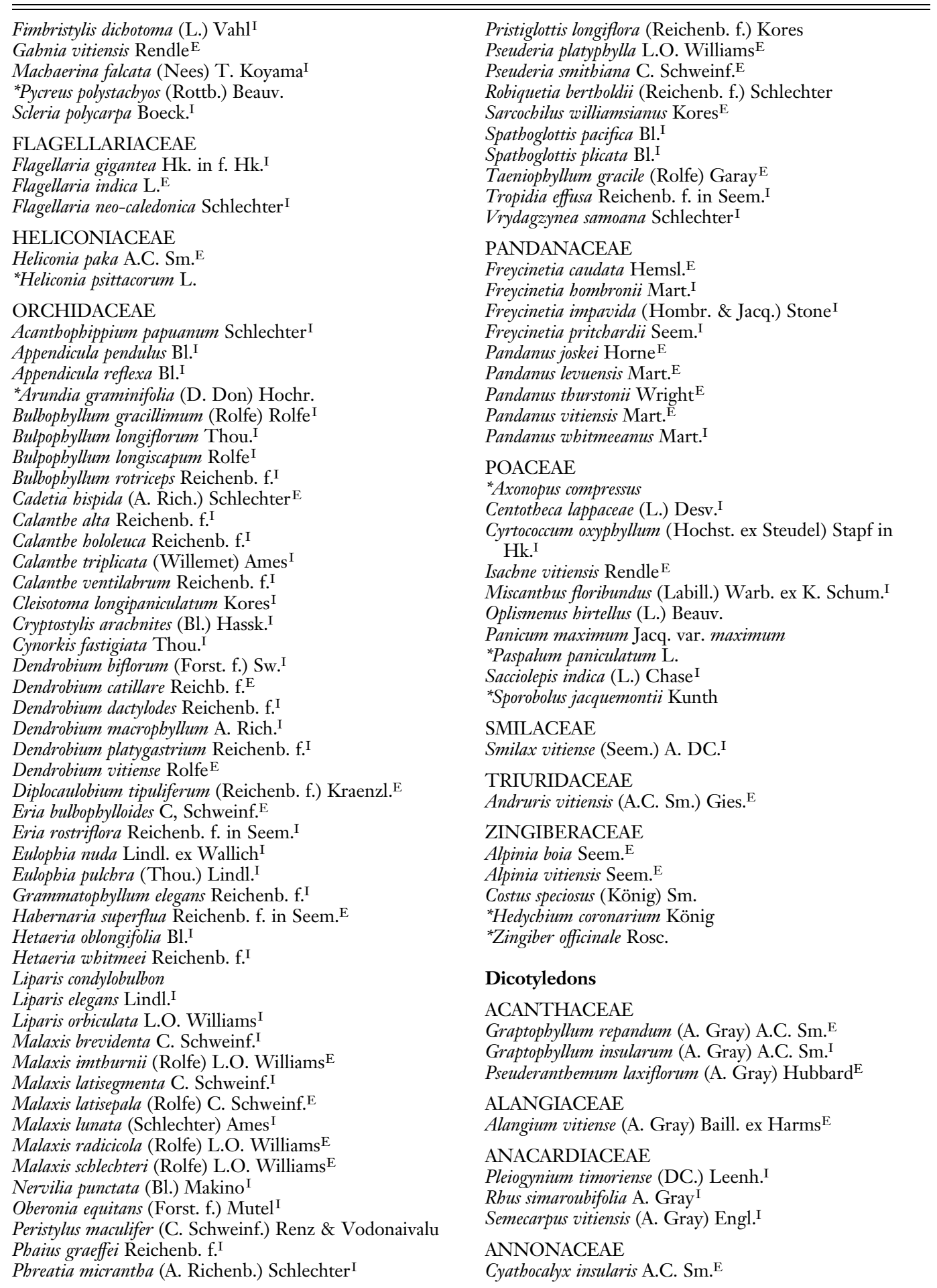


Appendix 1 (continued)

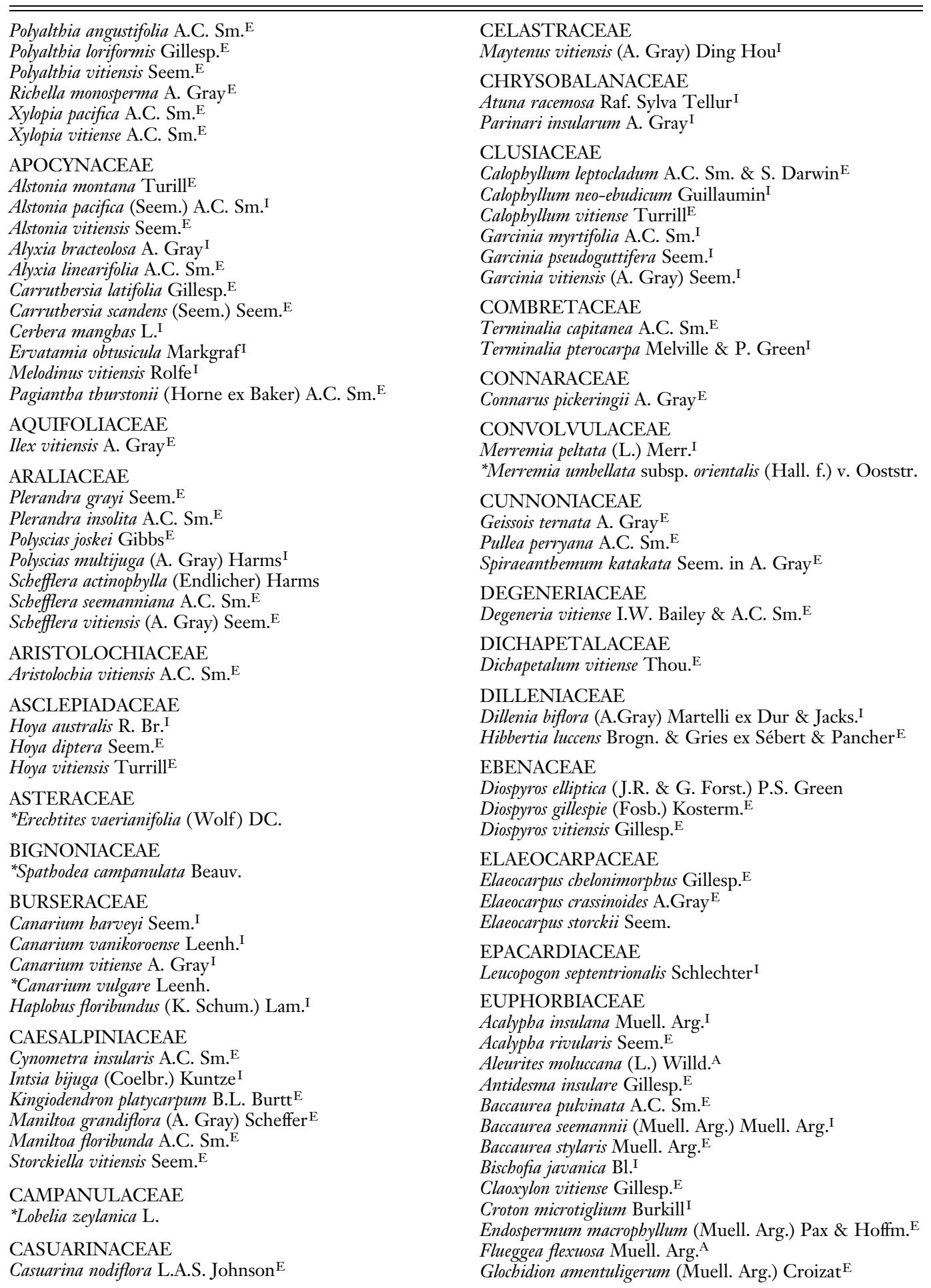


Appendix 1 (continued)

\begin{tabular}{|c|c|}
\hline Glochidion atrovirens A.C. Sm. ${ }^{\mathrm{E}}$ & Geniostoma clavigerum A.C. Sm. \& Stone $\mathrm{E}^{\mathrm{E}}$ \\
\hline Glochidion bracteatum Gillesp. $^{\mathrm{E}}$ & Geniostoma confertiflorum A.C. Sm. \& Stone $\mathrm{E}^{\mathrm{E}}$ \\
\hline Glochidion vitiensis (Muell. Arg.) Gillesp. ${ }^{\mathrm{E}}$ & Geniostoma macrophyllum Gillespie ${ }^{\mathrm{E}}$ \\
\hline Macaranga caesariata A.C. Sm. & Geniostoma rupestre J.R. \& G. Forst. ${ }^{I}$ \\
\hline Macaranga graeffeana $\mathrm{Pax} \& \mathrm{Hoffm} .{ }^{\mathrm{E}}$ & Geniostoma uninervium A.C. Sm. \& Stone $\mathrm{E}^{\mathrm{E}}$ \\
\hline Macaranga magna Turrille & Neuburgia alata (A.C. Sm.) A.C. Sm. ${ }^{\mathrm{E}}$ \\
\hline Macaranga seemannii (Muell. Arg.) Muell. Arg. ${ }^{\mathrm{E}}$ & Neuburgia corynocarpa (A. Gray) Leenh. ${ }^{\mathrm{E}}$ \\
\hline $\begin{array}{l}\text { Macaranga vitiensis } \text { Pax \& Hoffm. }{ }^{\mathrm{E}} \\
\text { Phyllantbus pregracilis Gillesp. }{ }^{\mathrm{E}} \\
{ }^{*} \text { Phyllantbus urinaria } \mathrm{L} .\end{array}$ & $\begin{array}{l}\text { LORANTHACEAE } \\
\text { Decaisnia forsteriana (J.A. \& H.Schultes) Barlow }{ }^{\mathrm{I}}\end{array}$ \\
\hline $\begin{array}{l}\text { FABACEAE } \\
* \text { * }\end{array}$ & $\begin{array}{l}\text { MALPIGHIACEAE } \\
\text { Hiptage myrtifolia A. Gray }\end{array}$ \\
\hline $\begin{array}{l}\text { Derris trifoliata Lour. } \\
\text { Inocarpus fagiferus (Parkinson) Fosb. }\end{array}$ & $\begin{array}{l}\text { MALVACEAE } \\
{ }^{*} \text { Urena lobata L. }\end{array}$ \\
\hline $\begin{array}{l}\text { FLACOURTIACEAE } \\
\text { Caesaria richii A. Gray }{ }^{\mathrm{E}} \\
\text { Erythrospermum acuminatissimum (A. Gray) A.C. Sm. } \\
\text { Flacourtia degeneri } \text { A.C. Sm. } \\
\text { Flacourtia subintegra } \text { A.C. Sm. }{ }^{\mathrm{E}} \\
\text { Homalium nitens Turrill }{ }^{\mathrm{E}} \\
\text { Homalium vitiensis Benth. }{ }^{\mathrm{E}}\end{array}$ & $\begin{array}{l}\text { MELASTOMATACEAE } \\
\text { Astronidium confertiflolium (A. Gray) Markgraf E } \\
\text { Astronidium floribundum (Gillesp.) A.C. Sm. }{ }^{\mathrm{E}} \\
\text { Astronidium lepidotum A.C. Sm. }{ }^{\mathrm{E}} \\
\text { Astronidium parviflorum A. Gray } \\
\text { Astronidium robustum (Seem.) A.C. Sm. }{ }^{\mathrm{E}} \\
\text { Astronidium saulae A.C. Sm. }{ }^{\mathrm{E}}\end{array}$ \\
\hline $\begin{array}{l}\text { GESNERIACEAE } \\
\text { Cyrtandra anthropophagorum Seem. }{ }^{\mathrm{E}} \\
\text { Cyrtandra cephalophora Gillesp. }{ }^{\mathrm{E}} \\
\text { Cyrtandra milnei Seem. ex A. Gray } \\
\text { Cyrtandra pritchardii } \text { Seem. } \\
\text { Cyrtandra trichophylla A.C. Sm. }{ }^{\mathrm{E}} \\
\text { Cyrtandra vitiensis Seem. }{ }^{\mathrm{E}}\end{array}$ & $\begin{array}{l}\text { Astronidium storckii } \text { Seem. }{ }^{\mathrm{E}} \\
{ }^{*} \text { Clidemia birta } \text { (L.) D. Don } \\
\text { Medinilla archboldiana } \text { A.C. Sm.E } \\
\text { Medinilla beteropbylla } \text { A. Gray }{ }^{\mathrm{E}} \\
\text { Medinilla longicymosa } \text { Gibbs } \\
\text { Medinilla ovalifolia } \text { (A. Gray) A.C. Sm. }{ }^{\mathrm{E}} \\
\text { Medinilla rhodochlaena } \text { A. Gray }{ }^{\mathrm{E}} \\
\text { Melastoma denticulatum } \text { Labill. }\end{array}$ \\
\hline $\begin{array}{l}\text { GOODENIACEAE } \\
\text { Scaevola floribunda A. Gray }{ }^{\mathrm{E}}\end{array}$ & $\begin{array}{l}\text { MELIACEAE } \\
\text { Aglaia arcbboldiana A.C. Sm. }{ }^{\mathrm{E}}\end{array}$ \\
\hline $\begin{array}{l}\text { HERNANDIACEAE } \\
\text { Hernandia olivacea } \text { Gillesp. }{ }^{\mathrm{E}}\end{array}$ & $\begin{array}{l}\text { Aglaia axillaris A.C. } \mathrm{Sm}^{\mathrm{E}} \\
\text { Aglaia elegans } \text { Gillespie }\end{array}$ \\
\hline $\begin{array}{l}\text { ICACINACEAE } \\
\text { Citronella vitiensis } \mathrm{R} \text {. Howard } \mathrm{E} \\
\text { Medusanthera vitiensis Seem. }{ }^{\mathrm{E}}\end{array}$ & $\begin{array}{l}\text { Aglaia greenwoodii A.C. Sm. }{ }^{\mathrm{E}} \\
\text { Aglaia vitiensis A.C. Sm. }{ }^{\mathrm{E}} \\
\text { Dysoxylum gillespianum A.C. Sm. } \\
\text { Dysoxylum bornei A.C. Sm. }\end{array}$ \\
\hline LAURACEAE & Dysoxylum lenticellare Gillesp. ${ }^{\mathrm{E}}$ \\
\hline Cinnamomum fitianum (Meisn.) A.C. Sm. ${ }^{\mathrm{E}}$ & Dysoxylum quercifolium (Seem.) A.C. Sm. ${ }^{\mathrm{E}}$ \\
\hline & $\begin{array}{l}\text { Dysoxylum richii (A. Gray) C. DC. } \\
\text { Dysoxylum seemannii Gillesp. }\end{array}$ \\
\hline Cryptocarya fusca Gillesp. ${ }^{\mathrm{E}}$ & ${ }^{*}$ Swietenia macrophylla King $^{\mathrm{N}}$ \\
\hline Cryptocarya hornei Gillesp. ${ }^{\mathrm{I}}$ & Vavaea amicorum Benth. ${ }^{\mathrm{I}}$ \\
\hline Endiandra elaeocarpa Gillesp. ${ }^{\mathrm{I}}$ & Vavaea harveyii Seem. ${ }^{\mathrm{E}}$ \\
\hline Endiandra gillespie A.C. Sm. E & Vavaea megaphylla C.H. Wright ${ }^{\mathrm{E}}$ \\
\hline $\begin{array}{l}\text { Endiandra gillespie A.C. Sm. }{ }^{\mathrm{E}} \\
\text { Endiandra monticola A.C. Sm. }{ }^{\mathrm{E}} \\
\text { Litsea magnifolia Gillesp. }{ }^{\mathrm{E}}\end{array}$ & $\begin{array}{l}\text { MENINSPERMACEAE } \\
\text { Pachygone vitiensis Diels }{ }^{\mathrm{I}}\end{array}$ \\
\hline Litsea vitiana (Meisn.) Benth. \& Hook. ${ }^{\mathrm{E}}$ & MIMOSACEAE \\
\hline $\begin{array}{l}\text { LECYTHIDACEAE } \\
\text { Barringtonia edulis Seem. }{ }^{\mathrm{E}} \\
\text { Barringtonia seaturae Guppy. }\end{array}$ & $\begin{array}{l}\text { Acacia richii } \mathrm{A} \text {. Gray }{ }^{\mathrm{E}} \\
{ }^{*} \text { Adenanthera pavonina } \mathrm{L} . \\
{ }^{*} \text { Albizia falcataria }(\mathrm{L} .) \text { Fosb. } \\
\text { Entada phaseoloides } \text { (L.) Merr. }{ }^{\mathrm{I}}\end{array}$ \\
\hline $\begin{array}{l}\text { LINACEAE } \\
\text { Durandea vitiensis Stapf in } \mathrm{Hk}^{\mathrm{E}}\end{array}$ & $\begin{array}{l}\text { *Samanea saman (Jacq.) Merrill } \\
\text { Serianthes melanesica var. melanesica Fosb. I (var. E) }\end{array}$ \\
\hline $\begin{array}{l}\text { LOBELIACEAE } \\
\text { *Lobelia zelyanica } \mathrm{L} .\end{array}$ & $\begin{array}{l}\text { MONIMIACEAE } \\
\text { Hedycarya dorstenoides A. Gray. }{ }^{\mathrm{I}}\end{array}$ \\
\hline $\begin{array}{l}\text { LOGANIACEAE } \\
\text { Fagraea gracilipes A. Gray }{ }^{\mathrm{I}}\end{array}$ & $\begin{array}{l}\text { MORACEAE } \\
\text { Ficus bambusifolia Seem. }{ }^{\mathrm{E}}\end{array}$ \\
\hline
\end{tabular}


Appendix 1 (continued)

\begin{tabular}{|c|c|}
\hline Ficus barclayana (Miq.) Summerh. ${ }^{\mathrm{E}}$ & OLEACEAE \\
\hline Ficus fulvo-pilosa Summerh. ${ }^{\mathrm{E}}$ & Chionanthus vitiensis (Seem.) A.C. Sm. ${ }^{\mathrm{I}}$ \\
\hline Ficus greenwoodii Summerh. ${ }^{\mathrm{E}}$ & Fasminum betchei F.v. Muell. I \\
\hline Ficus masonii Horne ex Baker & Fasminum didymum Forst. f. subsp. didymum ${ }^{\mathrm{I}}$ \\
\hline Ficus pritchardii Seem. & Fasminum simplicifolium Forst.f. subsp. simplicifolium ${ }^{\mathrm{I}}$ \\
\hline Ficus smithii Horne ex Barker ${ }^{\mathrm{E}}$ & PASSIFLORACEAE \\
\hline $\begin{array}{l}\text { Ficus storckii Seem. } \\
\text { Ficus theophrastoides Seem. }{ }^{\mathrm{E}}\end{array}$ & *Passiflora foetida $\mathrm{L}$. \\
\hline Ficus vitiensis Seem. ${ }^{\mathrm{E}}$ & $\begin{array}{l}\text { PEPPEROMIACEAE } \\
\text { Pepperomia lasiostigma C. DC. }\end{array}$ \\
\hline MYRISTICACEAE & Pepperomia purpuroides Yuncker $^{\mathrm{E}}$ \\
\hline Myristica castaneifolia A. Gray ${ }^{\mathrm{E}}$ & PIPERACEAE \\
\hline Myristica chartaceae Gillesp. ${ }^{\mathrm{E}}$ & Macropiper melanostachyum (C. DC.) A.C. Sm. ${ }^{\mathrm{I}}$ \\
\hline & Macropiper oxycarpum (C. DC.) A.C. Sm. ${ }^{\mathrm{E}}$ \\
\hline $\begin{array}{l}\text { Myristica grandifolia A. DC. } \\
\text { Myristica macrantha A.C. Sm. }\end{array}$ & $\begin{array}{l}\text { Macropiper puberulum Benth. }{ }^{\text {" }} \\
{ }^{*} \text { Piper aduncum } \text { L. }\end{array}$ \\
\hline MYRSINACEAE & Piper insectifugum C. DC. ${ }^{\mathrm{E}}$ \\
\hline Discocalyx fusca Gibbs $^{\mathrm{E}}$ & PITTOSPORACEAE \\
\hline Maesa insularis Gillesp. ${ }^{\mathrm{E}}$ & Pittosporum brackenridgei A. Gray I \\
\hline Maesa tabacifolium $\mathrm{Mez}^{\mathrm{I}}$ & Pittosporum oligodontum Gillespie $^{\mathrm{E}}$ \\
\hline Maesa vitiensis Seem ${ }^{\mathrm{E}}$ & Pittosporum pickeringii A. Gray ${ }^{\mathrm{E}}$ \\
\hline Rapanea myricifolia (A. Gray) Mez & Pittosporum rbytidocarpum A. Gray ${ }^{\mathrm{E}}$ \\
\hline Tapeinosperma ampliflorum A.C. Sm. ${ }^{\mathrm{E}}$ & POLYGALACEAE \\
\hline $\begin{array}{l}\text { Tapeinosperma capitatum (A. Gray) Mez }{ }^{\mathrm{E}} \\
\text { Tapeinosperma clavatum Mez }\end{array}$ & *Polygala paniculata $\mathrm{L}$. \\
\hline Tapeinospermum ligulifolium A.C. Sm. ${ }^{\mathrm{E}}$ & PROTEACEAE \\
\hline Tapeinosperma hornei $\mathrm{Mez}^{\mathrm{E}}$ & $\begin{array}{l}\text { Turillia ferruginea (A.C. Sm.) A.C. Sm. }{ }^{\mathrm{E}} \\
\text { Turillia vitiensis (Turrill) A.C. Sm. }{ }^{\mathrm{E}}\end{array}$ \\
\hline $\begin{array}{l}\text { MYRTACEAE } \\
\text { Cleistocalyx decussatus A.C. Sm.E }\end{array}$ & RANUNCULACEAE \\
\hline Cleistocalyx ellipticus (A.C. Sm.) Merr. \& Perry $\mathrm{E}$ & Clematis pickeringii A. Gray ${ }^{\mathrm{I}}$ \\
\hline Cleistocalyx eugenioides Merr. \& Perry ${ }^{\mathrm{E}}$ & RHAMNACEAE \\
\hline Cleistocalyx longiflorus (A.C. Sm.) Merr \& Perry ${ }^{\mathrm{E}}$ & Alphitonia franguloides A. Gray ${ }^{\mathrm{I}}$ \\
\hline Decaspermum vitiense (A. Gray) Niedenzu ${ }^{\mathrm{E}}$ & Alphitonia zizyphoides (Spreng.) A. Gray ${ }^{\mathrm{I}}$ \\
\hline${ }^{*}$ Melaleuca quinquenervia (Cav.) S.T. Blake & Emmenosperma micropetalum (A.C. Sm.) M. Johnst. ${ }^{\mathrm{E}}$ \\
\hline $\begin{array}{l}\text { Metrosideros collina (J.R. \& G. Forst.) A. Gray var. collina }{ }^{\mathrm{I}} \\
\text { Metrosideros collina var. villosa (L.f.) A. Grav }\end{array}$ & RHIZOPHORACEAE \\
\hline $\begin{array}{l}\text { Metrosideros collina var. villosa (L.t.) A. Gray }{ }^{1} \\
\text { Metrosideros collina var. fruticosa J.W. Moore }\end{array}$ & Crossostylis harveyi Benth. \\
\hline Syzygium amicorum (A. Gray) C. Muell. E & Crossostylis richii (A. Gray) A.C. Sm. ${ }^{\mathrm{E}}$ \\
\hline Syzygium amplifolium Perry $\mathrm{E}$ & Crossostylis seemannii (A.Gray) Schimper $\mathrm{E}$ \\
\hline Syzygium brackenridgei (A. Gray) C. Muell.I & ROSACEAE \\
\hline Syzygium confertiflorum (A. Gray) C. Muell. ${ }^{\mathrm{E}}$ & Rubus moluccanus $\mathrm{L}$. var. ausropacificus $\mathrm{v}$. Royen ${ }^{\mathrm{I}}$ \\
\hline Syzygium corynocarpum (A. Gray) C. Muell. ${ }^{\mathrm{I}}$ & RUBIACEAE \\
\hline $\begin{array}{l}\text { Syzygium curvistylum (Gillesp.) Merr. \& Perry } \mathrm{I} \\
\text { Syzygium diffusum (Turrill) Merr. \& Perry }{ }^{\mathrm{E}}\end{array}$ & Airosperma trichotomum (Gillesp.) A.C. Sm. ${ }^{\mathrm{E}}$ \\
\hline Syzygium effusum (A. Gray) C. Muell. ${ }^{I}$ & Antirhea smithii (Fosb.) Merr. \& Perry ${ }^{\mathrm{E}}$ \\
\hline Syzygium fijiense Perry ${ }^{\mathrm{E}}$ & Cyclophyllum barbatum (Forst. f.) A.C. Sm. ${ }^{\text {I }}$ \\
\hline Syzygium gillespiei Merr. \& Perry E & Dolchiolobium latifolium A. Gray ${ }^{\mathrm{E}}$ \\
\hline Syzygium gracilipes (A. Gray) Merr. \& Perry ${ }^{\mathrm{E}}$ & $\begin{array}{l}\text { Dolchiolobium macgregorii Horne ex Baker }{ }^{\mathrm{E}} \\
\text { Dolchiolobium oblonoifolium A. Grav }\end{array}$ \\
\hline $\begin{array}{l}\text { Syzygium grayii (Seem.) Merr. \& Perry }{ }^{\mathrm{E}} \\
\text { Syzygium leucanthum } \text { Perry }^{\mathrm{E}}\end{array}$ & $\begin{array}{l}\text { Dolchiolobium oblongifolium A. Gray } \\
\text { Gardenia gordonii BakerE }\end{array}$ \\
\hline Syzygium malaccense (L.) Merr. \& Perry ${ }^{\mathrm{A}}$ & Gardenia grievei Horne ex Baker ${ }^{\mathrm{E}}$ \\
\hline Syzgium pupureum (Perry) A.C. Sm.E & Gardenia storckii Oliver ${ }^{\mathrm{I}}$ \\
\hline Syzygium rubescens (A. Gray) C. Muell. ${ }^{\mathrm{E}}$ & Geophila repens (L.) I.M. Johnst.I \\
\hline Syzygium simillimum Merr. \& Perry E & $\begin{array}{l}\text { Gynochtodes epiphyta (Rech.) A.C. Sm. \& S. Darw.' } \\
\text { Hedyotis lapeyrousii DC. }\end{array}$ \\
\hline NYCTAGINACEAE & Hydnophytum longiflorum A. Gray ${ }^{\mathrm{E}}$ \\
\hline Pisonia umbellifera (J.R. \& G. Forst.) Seem. & Ixora amplexicaulis Gillesp. ${ }^{\mathrm{E}}$ \\
\hline OLACACEAE & Ixora elegans Gillesp. ${ }^{\mathrm{E}}$ \\
\hline Anacolosa lutea Gillesp. ${ }^{\mathrm{I}}$ & Ixora maxima Seem. $\mathrm{E}$ \\
\hline
\end{tabular}


Appendix 1 (continued)

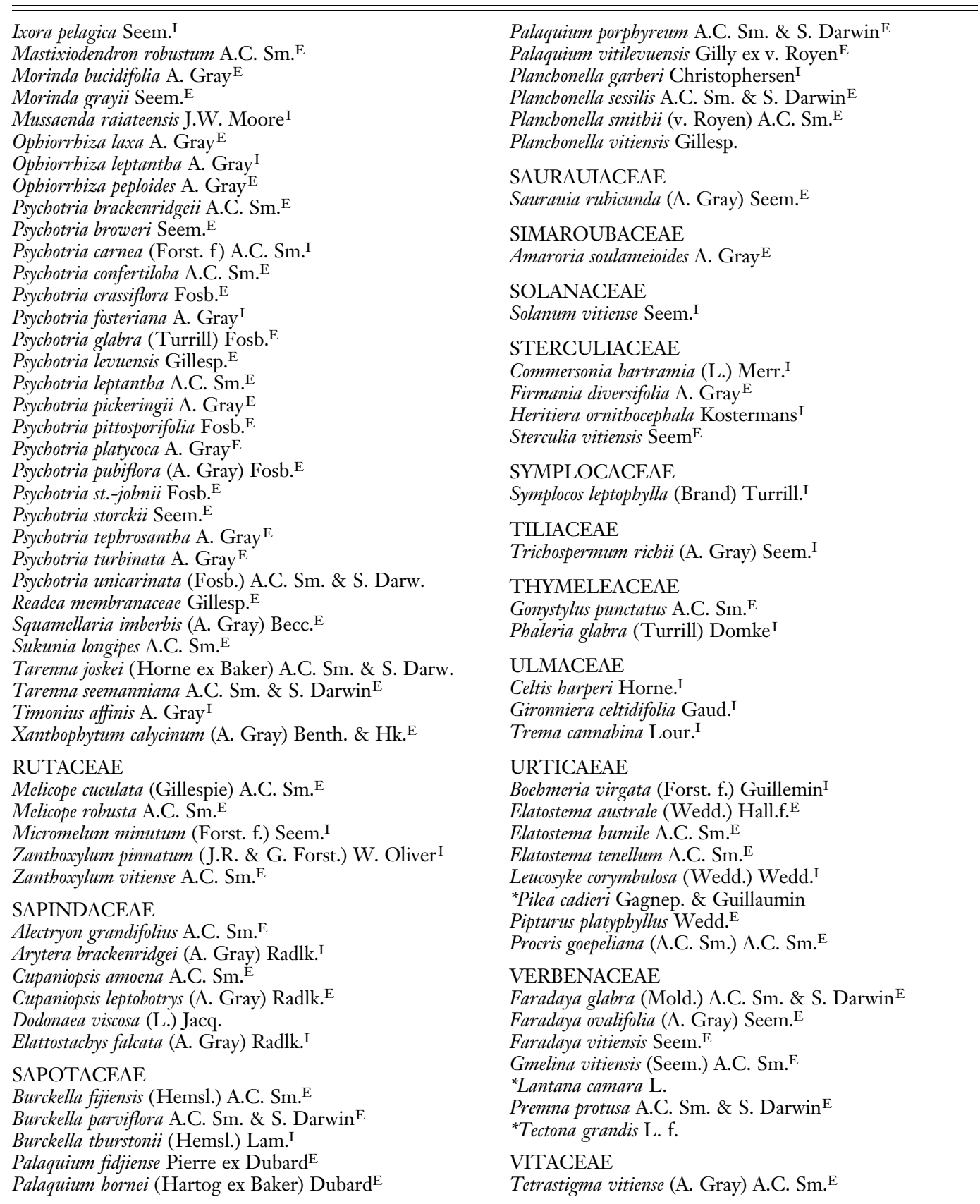

Sources: Species records are derived from Smith $(1979,1981,1985,1988,1991,1996)$, the database of the South Pacific Regional Herbarium, and Kirkpatrick and Hassal (1985).

Note: Nomenclature follows Smith (1979, 1981, 1985, 1988, 1991, 1996), Brownlie (1977), and Doyle (1998).

*, Recent introduction.

I, Indigenous.

E, Endemic.

A, Aboriginal introduction. 


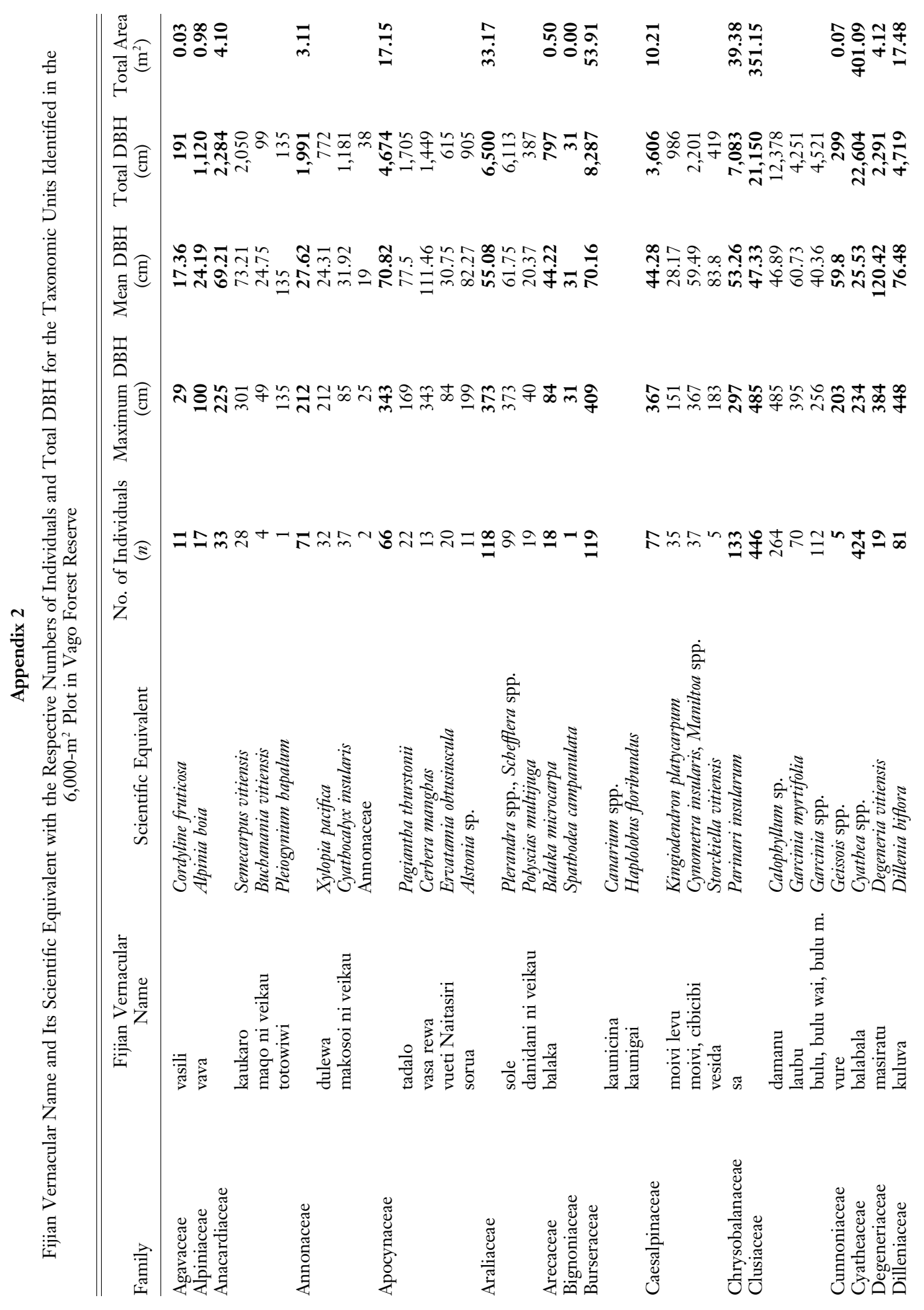




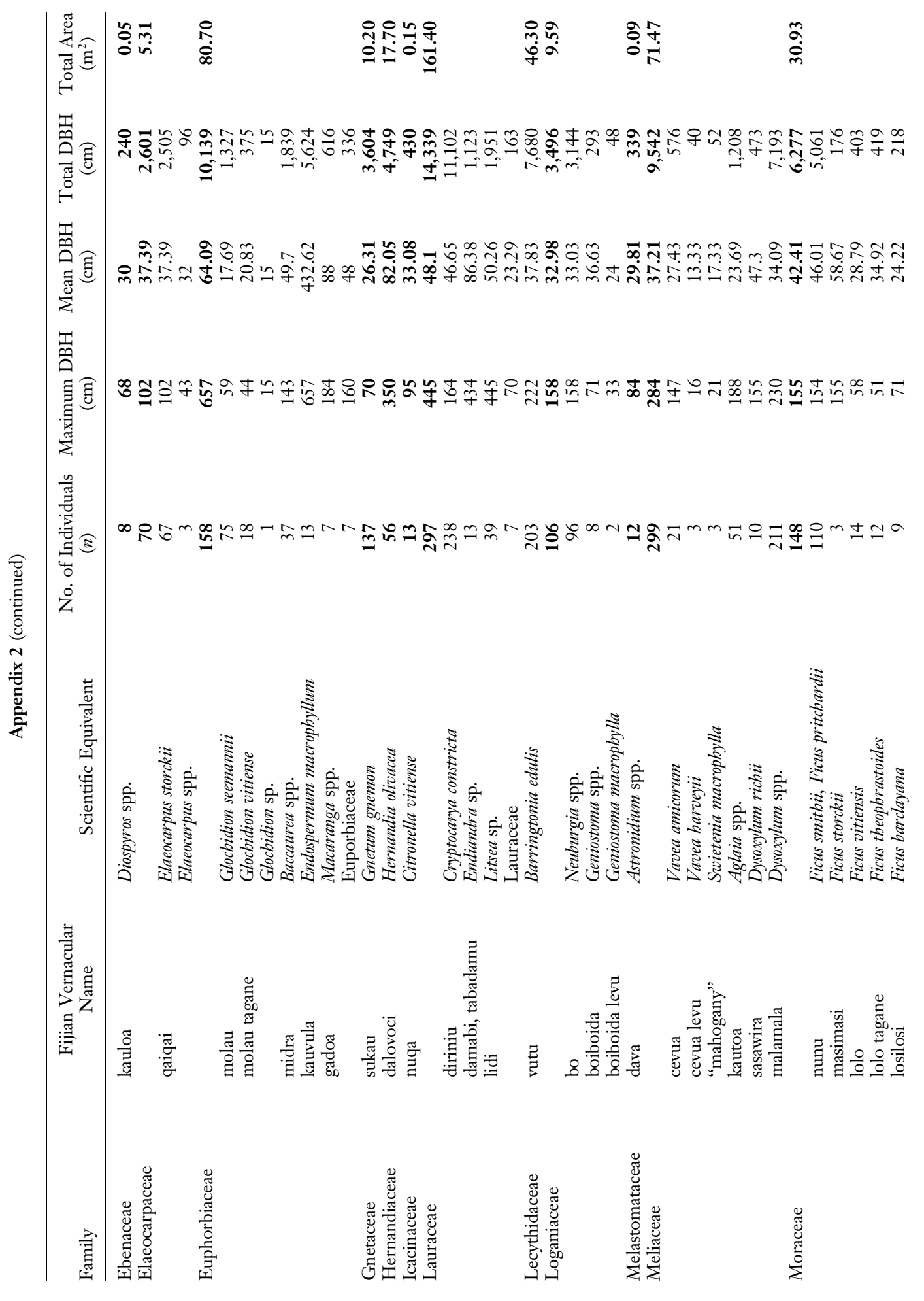




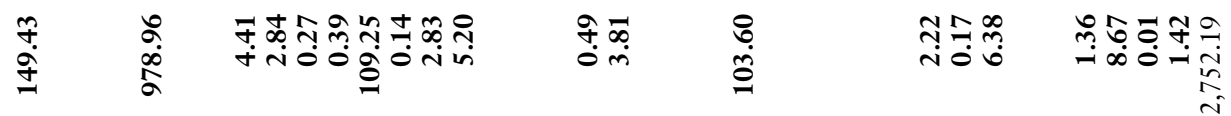

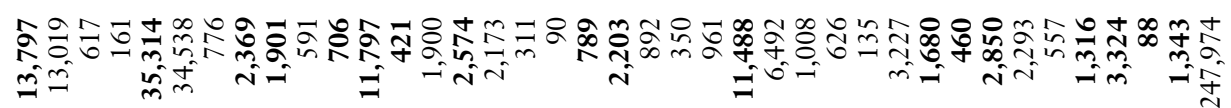

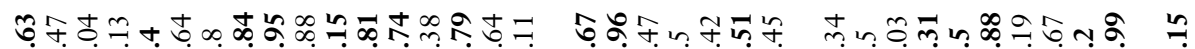

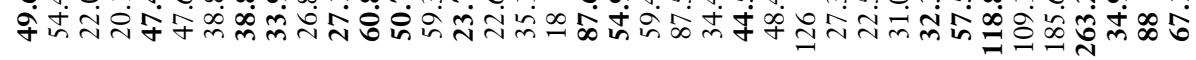

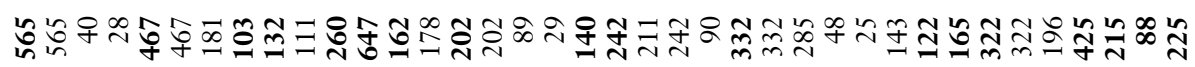

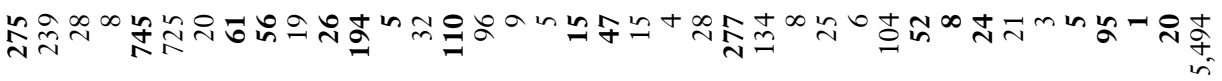

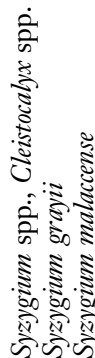
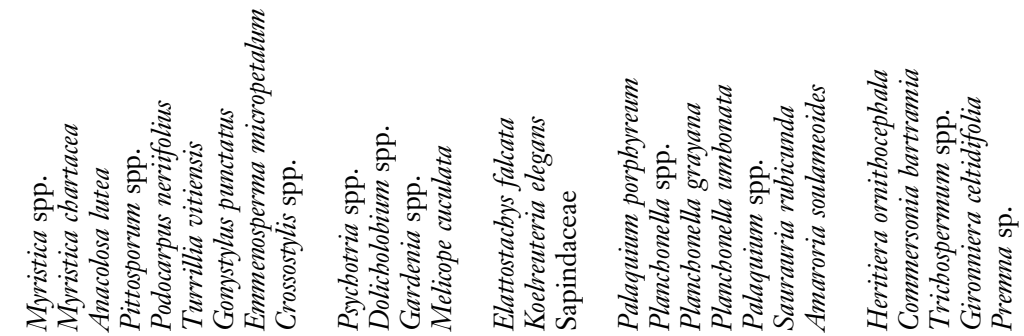

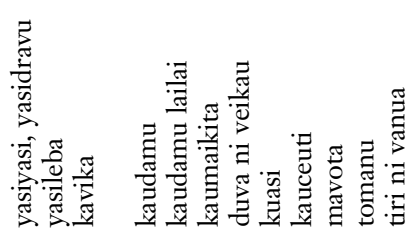<smiles>C[C@H]1[C@@H]2C[C@H]1C=C[C@@H]2C</smiles>

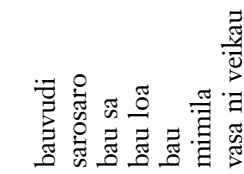

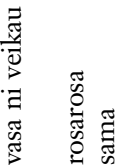


